Lejonberg, E., Elstad, E. \& Christophersen, K.A. (2017). Teaching evaluation: antecedents of teachers' perceived usefulness of follow-up sessions and perceived stress related to the evaluation process. Teachers and Teaching: theory and practice.

http://www.tandfonline.com/doi/full/10.1080/13540602.2017.1399873

\title{
Teaching evaluation: antecedents of teachers' perceived usefulness of follow-up sessions and perceived stress related to the evaluation process
}

\begin{abstract}
This study examines teaching evaluation based on student feedback which is intended to contribute to teachers' professional development. Although studies have highlighted that teaching evaluation is a potential source of professional development and that follow-up sessions are crucial to this benefit, little attention has been paid to the usefulness of follow-up sessions as perceived by the teachers involved. Based on 217 teacher responses and analysis done with Structural Equation Modelling, this article provides additional insight into teaching evaluation by investigating possible antecedents for teachers' perceived usefulness of followup sessions and for evaluation related stress. Our results indicates that the perceived developmental purposes of teaching evaluation, recognition of the person conducting followup sessions and perceived clear communication from leaders are positively related to teachers' perceived usefulness of follow-up sessions. Higher levels of perceived control purposes are related to higher levels of reported stress among the evaluated teachers.
\end{abstract}

Keywords: Teaching evaluation, teacher evaluation, follow-up sessions, teacher stress, continuing professional development, feedback from students, mentoring experienced teachers.

\section{Introduction}

In recent years, an increasing number of education authorities has implemented teaching evaluation schemes (Isoré, 2009; see also Skrøwseth, 2008; Organisation for 
Lejonberg, E., Elstad, E. \& Christophersen, K.A. (2017). Teaching evaluation: antecedents of teachers' perceived usefulness of follow-up sessions and perceived stress related to the evaluation process. Teachers and Teaching: theory and practice.

http://www.tandfonline.com/doi/full/10.1080/13540602.2017.1399873

Economic Cooperation and Development, 2009, 2011; Ovando \& Ramirez, 2007). The evaluation of teachers' performance is often considered an important strategic approach for professional development (Bartlett, 1998; Kuvaas, 2011). Teaching evaluation is the systematic process in which school leaders periodically critique teachers' work performance based on student feedback. Although teacher evaluation is the most commonly used term in research on this topic, we employ the term teaching evaluation to denote evaluation specifically based on student's feedback. Teaching evaluation is the consensus-based term used by the actors involved in discussions on the implementation of such an evaluation scheme in Norway (Elstad, Lejonberg, \& Christophersen, 2015).

Teaching evaluation has the potential to contribute to teachers' professional development by providing information for reflection on teaching practice (Conley, Smith, Collinson, \& Palazuelos, 2016; Darling-Hammond, Wise, \& Pease, 1983). However, developing and leading teaching evaluation systems which improve practice are challenging (Darling-Hammond, Amrein-Beardsley, Haertel, \& Rothstein, 2011). The relationship between evaluation and development is 'troublesome' because evaluation does not necessarily contribute to any improvement in teachers' educational practice (Smylie, 2014, p. 97). Instead, teaching evaluation might trigger unnecessary teacher stress, which is often cited as an argument against the implementation of teaching evaluation systems (Kelly, Ang, Chong, \& Hu, 2008). Despite the assumed link between teaching evaluation and teacher stress (Austin, Shah, \& Muncer, 2005; Kyriacou \& Sutcliffe, 1978; Litt \& Turk, 1985), little is known about the empirical associations between stress and possible predictors.

Helpful feedback is among the key factors assumed to be needed for teaching evaluation systems to contribute to teachers' professional development (Darling-Hammond et 
Lejonberg, E., Elstad, E. \& Christophersen, K.A. (2017). Teaching evaluation: antecedents of teachers' perceived usefulness of follow-up sessions and perceived stress related to the evaluation process. Teachers and Teaching: theory and practice.

http://www.tandfonline.com/doi/full/10.1080/13540602.2017.1399873

al., 2011; Duke \& Stiggins, 1986; Elstad, 2014; Firestone, 2014; Flores, 2010;

Fylkeskommune, 2014; Guskey, 2002; Hill \& Grossman, 2013; Machell, 1995; Mo, Conners, \& McCormick, 1998). Delvaux et al. (2013b, p. 8) describe the perceived utility of feedback as 'the most important of all included components' in their study investigating the relation between teachers' professional development and 10 predictive variables. However, the assumption that supervisors contribute to improved performance through follow-up sessions is problematic (Flores, 2010; Kuvaas \& Dysvik, 2012). The beneficial effects of feedback do not necessarily emerge from such sessions (Wright, 2004), and negative effects can even result (Kluger \& DeNisi, 1996). Employees' reactions to being evaluated are also assumed to be important for beneficial outcomes to follow performance appraisal (Levy \& Williams, 2004; Nishii, Lepak, \& Schneider, 2008). More specifically, employees’ perceptions of follow-up sessions as useful are assumed to be essential to professional development (Blau, 1999; Kuvaas, 2012).

The overall aim of this article is to identify conditions that can promote evaluationbased professional development among teachers. This work contributes to knowledge about evaluations of teacher and the leaders' follow-up sessions to teachers' professional development. The study focuses on two research questions:

1) What antecedents are associated with teachers' perceived usefulness of follow-up sessions?

2) What antecedents are associated with teachers' perceived stress related to the teaching evaluation process? 
Lejonberg, E., Elstad, E. \& Christophersen, K.A. (2017). Teaching evaluation: antecedents of teachers' perceived usefulness of follow-up sessions and perceived stress related to the evaluation process. Teachers and Teaching: theory and practice.

http://www.tandfonline.com/doi/full/10.1080/13540602.2017.1399873

\section{Context}

Modern views see teachers' professional development as occurring over a long professional lifespan, starting with teacher education and continuing throughout the professional career (Richter, Kunter, Klusmann, Lüdtke, \& Baumert, 2011). However, researchers have underlined that professional development opportunities for teachers must be adapted to the involved teachers and perceived as valuable for professional development to happen (Day \& Gu, 2007; Day et al., 2006). Others have underlined that professional development opportunities are more likely to be effective if they are linked to the teachers' on going daily work and aligned with earlier experiences (Garet, Porter, Desimone, Birman, \& Yoon, 2001). Many European countries and US states have implemented evaluation schemes to facilitate teachers' development. However, TALIS 2013 shows that Norwegian teachers receive little feedback on their professional practice (OECD, 2014). The OECD has also reported the absence of systematic assessment of teachers in Norway (OECD, 2011). How teaching evaluations are carried out and used differ significantly throughout the country.

In the district where data for this study were collected, pupils have assessed teachers' instructional performance through anonymous surveys since 2010. Teaching evaluation is carried out as follows. Teachers are involved in identifying which students should evaluate which teachers. Students then complete a standardized survey in which they express their views about the relevant teachers' teaching (see appendix). After some time, teachers receive the assessment results and should then present them to the class that evaluated the teacher. The students are expected to elaborate and explain the results and contribute to teachers' interpretation and development. According to principals, almost all teachers conduct such conversations in their classes (Brunvoll, 2014). In the follow-up sessions teachers and their 
Lejonberg, E., Elstad, E. \& Christophersen, K.A. (2017). Teaching evaluation: antecedents of teachers' perceived usefulness of follow-up sessions and perceived stress related to the evaluation process. Teachers and Teaching: theory and practice.

http://www.tandfonline.com/doi/full/10.1080/13540602.2017.1399873

nearest leader and discuss the results and how they can improve their teaching. An agreement signed by the teacher and leader justifies the teacher's suggested actions and sets a deadline for implementation (Akershus County, 2014). However, as many as $38 \%$ of principals in the county reported that only some teachers had concrete developmental goals after follow-up sessions with their leaders (Brunvoll, 2014). The usefulness of these follow-up sessions and teachers' accompanying stress constitute the focus of this article.

The heavy dependence on student feedback is unique internationally. The inclusion of students in the evaluation is to counterbalance the asymmetrical power relationship between teachers and students, and to accommodate students democratic right to be heard in matters important to them (Elstad et al., 2015). The democratic involvement of students can be understood in light of the strong 'egalitarian philosophy' in Scandinavia, characterised by social democratic values and the concept of inclusive schools (Blossing, Imsen, \& Moos, 2013, p. 1; Helgøy \& Homme, 2006). The overall reception of student-based teaching evaluation in Norway has been quite positive, although teachers and others have questioned students' ability to evaluate teaching and the rationale behind such consumer-oriented assessments (Jambak, 2015). Others have found that students' views of good teaching differ with age (Bakx, Koopman, de Kruijf, \& den Brok, 2015). Therefore, it is relevant to note that the students in the investigated context are mostly $16-18$ years old. In $2014,79 \%$ of the principals in the investigated county reported that teaching evaluation was beneficial for teachers to at least a great extent, 1 or 2 on a 1-5 scale (Brunvoll, 2014). The student survey, the basis of the teaching evaluation scheme, was developed on the community level by students, teachers and policy makers, with technical support from consultants. 
Lejonberg, E., Elstad, E. \& Christophersen, K.A. (2017). Teaching evaluation: antecedents of teachers' perceived usefulness of follow-up sessions and perceived stress related to the evaluation process. Teachers and Teaching: theory and practice.

http://www.tandfonline.com/doi/full/10.1080/13540602.2017.1399873

\section{Hypotheses}

Our theoretical model has two dependent variables: the perceived usefulness and stress of follow-up sessions in teaching evaluation. The perceived purposes of teaching evaluation, the clarity of communication with school leadership and teachers' level of recognition of the person responsible for the follow-up sessions are assumed to be related to the dependent variables and, therefore, are introduced as antecedents.

\subsection{Perceived purposes of evaluations as antecedents of the perceived usefulness and stress} of follow-up sessions

How employees perceive the purpose of implemented human-resources strategies has been found to be highly relevant to the outcomes of these strategies (Nishii et al., 2008). Scholars assume that it is important to "nurture an educational climate in which evaluation is not seen as punitive and that teachers are highly invested in the process' (Goe, Holdheide, \& Miller, 2013: 50). Deneire, Vanhoof, Faddar, Gijbels, and Van Petegem (2014) stress that 'appraisal should be interpreted as a constructive, developmental process' (p. 97). Smylie (2014) recommends that teaching evaluation systems to be explicitly linked to developmental purposes in order to have beneficial effects. The guidelines for the follow-up sessions focus on the potential for improvement and emphasise that the same issues should be kept in focus over several rounds of follow-up sessions to ensure development (Akershus County, 2013).

The follow-up sessions are based on the principle of confidentiality, focus on development and have no financial implications. However, research has shown that, although teaching evaluation is meant to serve developmental ends, alternative purposes might exert influence (Lillejord et al., 2014). For instance, an evaluation scheme could be used informally 
Lejonberg, E., Elstad, E. \& Christophersen, K.A. (2017). Teaching evaluation: antecedents of teachers' perceived usefulness of follow-up sessions and perceived stress related to the evaluation process. Teachers and Teaching: theory and practice.

http://www.tandfonline.com/doi/full/10.1080/13540602.2017.1399873

in making staffing or local merit pay decisions, even though the declared purpose is professional development. Even if evaluations are not used as a method of control, teachers nevertheless might perceive them as such, which might negatively affect their efforts and ability to derive useful information from the process. Indeed, such purposes can be combined (Isoré, 2009; Mo et al., 1998).

Recent research has shown that teachers' perceptions influence how they understand the purposes of evaluation influence. (Flores, 2012; Katsuno, 2010). Delvaux et al. (2013) found that, while perceived summative purposes had a small, significant effect on professional development, perceived development-oriented purposes did not. Given such conflicting evidence, we explore the statistical associations between the perceived usefulness of teaching evaluation and whether teachers perceive the purpose of evaluation as controlling them or contributing to their professional development. Therefore, we propose the following hypothesis:

H1: The perceived purpose of teaching evaluation is associated with the perceived usefulness of follow-up sessions.

Teaching evaluations can have counterproductive outcomes, such as stress (Kelly et al., 2008). Such disadvantages are often used to argue against implementation of teaching evaluation schemes. Abrahamsen and Aas (2014) describe Norwegian head teachers' efforts to reduce what they perceive as the control element of teaching evaluation and to make the follow-up sessions less intimidating for the teachers evaluated. We explore the associations between the perceived purposes and stress of teaching evaluation and formulate the following hypothesis: 
Lejonberg, E., Elstad, E. \& Christophersen, K.A. (2017). Teaching evaluation: antecedents of teachers' perceived usefulness of follow-up sessions and perceived stress related to the evaluation process. Teachers and Teaching: theory and practice.

http://www.tandfonline.com/doi/full/10.1080/13540602.2017.1399873

H2: The perceived purpose of teaching evaluation is associated with the evaluationrelated stress.

\subsection{Recognition of the person who conducts follow-up sessions as an antecedent of perceived usefulness and stress}

School leaders are expected to mentor teachers and contribute to their continuing professional development (Colbjørnsen, 2014). Developmental relationships at work are recognised to have great potential as drivers of professional development among employees (Clutterbuck, 2004; Kram, 1988). Tuytens and Devos (2012) describe the role of the leader as 'extremely important' to teachers' perceived feedback utility (p. 756). Recognition of the appraiser is a critical issue when implementing teaching evaluation schemes (Flores, 2010, 2012) as 'the relationship between the evaluator and the teacher is ... a critical factor for teachers' satisfaction ... and [the] effectiveness of an evaluation system' (Delvaux et al., 2013a, p. 3). However, combining the role of leader with those of evaluator and mentor faces possible challenges (Hobson, Ashby, Malderez, \& Tomlinson, 2009; Lejonberg, 2014; Skrøwseth, 2008). We assume that level of recognition is related to perceived utility and formulate the following hypothesis:

H3: Recognition of the person who conducts the follow-up session is associated with the perceived usefulness of the follow-up session.

We also hypothesise that recognition of the person who conducts the follow-up sessions is related to the potential stress of being evaluated (Austin et al., 2005; Kyriacou \& Sutcliffe, 1978; Litt \& Turk, 1985). 
Lejonberg, E., Elstad, E. \& Christophersen, K.A. (2017). Teaching evaluation: antecedents of teachers' perceived usefulness of follow-up sessions and perceived stress related to the evaluation process. Teachers and Teaching: theory and practice.

http://www.tandfonline.com/doi/full/10.1080/13540602.2017.1399873

H4: Recognition of the person who conducts the follow-up session is associated with the perceived evaluation-related stress.

\subsection{Clear communication as an antecedent of the perceived usefulness and stress of follow- up sessions}

Conducting teaching evaluation is the responsibility of school management. Whether managers communicate the school's goals and expectations in a way that gives teachers a clear understanding of what is desired from them is assumed to be relevant to whether an appraisal system promotes job satisfaction (Deneire et al., 2014) and whether follow-up sessions are perceived as useful (Heck, 1992). Others claim that understanding schools' goals is important for helping teachers to develop and refine their instructional practice (Leithwood, 1994). However, Delvaux et al. (2013) find that such efforts by leaders had no significant effect on professional development, while Tuytens and Devos (2010) report that whether teachers perceive principals as communicating the school's goals is related to whether they see the evaluation scheme as useful. There is an expressed expectation that school leaders will ‘set clear goals’ for teachers’ pedagogical work (Colbjørnsen, 2014, p. 257).

Some scholars argue that supervisors should not have too a clear form of dialogue as, for the sake of professional development, employees should have room to reflect and develop on their own terms (Handal \& Lauvas, 1987; Hobson \& Malderez, 2013). However, authors (in progress) also find beneficial outcomes of 'clear mentoring' characterised by unambiguous feedback, advice and communication in evaluation. This finding is in accordance with the work by Tuytens and Devos (2013), who show that clear communication of supervisors' expectations for teachers in the evaluation process is a characteristic of positively perceived 
Lejonberg, E., Elstad, E. \& Christophersen, K.A. (2017). Teaching evaluation: antecedents of teachers' perceived usefulness of follow-up sessions and perceived stress related to the evaluation process. Teachers and Teaching: theory and practice.

http://www.tandfonline.com/doi/full/10.1080/13540602.2017.1399873

schools. Skrøwseth (2008) highlights clear feedback as a driver of the beneficial outcomes of evaluation. Based on this mixed evidence, we propose the following hypotheses:

H5: Perceived clear communication with management is associated with the perceived usefulness of follow-up sessions.

H6: Perceived clear communication with management is associated with the perceived evaluation-related stress.

Based on the literature review and the hypotheses presented, we draw the following conceptual model:

[Figure 1 about here]

Theoretical model with perceived developmental purposes, perceived control purposes, recognition of the appraiser and clear communication as predictors of the perceived usefulness of follow-up sessions and the evaluation-related stress.

\section{Empirical investigation}

Data were gathered from teachers at five upper-secondary schools in the district in Norway which has most systematically implemented teaching evaluation scheme. The study was implemented by one of the authors of this article using the occasion of joint mandatory meetings with various teachers. The main features of the study were explained, and the teachers were informed that participation was voluntary. None of the teachers present at the time of the data gathering exercised their right to decline to participate. The results are 
Lejonberg, E., Elstad, E. \& Christophersen, K.A. (2017). Teaching evaluation: antecedents of teachers' perceived usefulness of follow-up sessions and perceived stress related to the evaluation process. Teachers and Teaching: theory and practice.

http://www.tandfonline.com/doi/full/10.1080/13540602.2017.1399873

estimated based on response from 217 teachers. The teachers entered no information that could reveal their identity, and the survey is thus fully anonymised.

\subsection{Methodology}

The investigated teachers responded to items in a survey on a seven-point Likert scale, where the alternative 'four' represented a neutral midpoint ranging from 1 (fully disagree) to 7 (fully agree)". Each concept was measured using three items. As the aim of this study was to illuminate associations between variables, Structural Equation Modelling (SEM) was used to estimate the strengths of the relationship between the independent and dependent variables. The questionnaire used in this study was based on recognised measurement instruments previously reported in the literature.

[Table 1 about here]

\subsection{Analysis}

SEM, which is suitable for confirmatory factor analysis and path analysis, was used to analyse the relationships among the variables. The analysis was based on Generalized Least Squares. Assessment of the fit between the model and the data was based on the following indices: root mean square error of approximation (RMSEA), normed fit index (NFI), goodness-of-fit index (GFI) and comparative fit index (CFI). RMSEA $<0.05$ and TLI, GFI and CFI $>0.95$ indicate good fit, while RMSEA $<0.08$ and TLI, GFI and CFI $>0.90$ indicate acceptable fit (Kline 2005).

The measurement and structural models were estimated using IBM SPSS Amos 22 and are based on 195 respondents. The obtained values for RMSEA, TLI, GFI and CFI indicate that the structural model presented in Figure 1 has an acceptable fit. In Figure 1, the 
Lejonberg, E., Elstad, E. \& Christophersen, K.A. (2017). Teaching evaluation: antecedents of teachers' perceived usefulness of follow-up sessions and perceived stress related to the evaluation process. Teachers and Teaching: theory and practice.

http://www.tandfonline.com/doi/full/10.1080/13540602.2017.1399873

ellipses represent the latent variables, the circles the measurement errors, and the rectangles the observed measured variables. The structural model consists of terms with paths (arrows) between them, which indicate theoretical common causes. The figures (standardised regression coefficients) represent the measured strength of the connections. Strength increases with numerical value.

[Figure 2 about here]

Figure 2. Estimated model $(\mathrm{N}=206)$. PUC = perceived usefulness of the follow-up session; STR $=$ perceived stress $; \mathrm{CC}=$ communication with leaders $; \mathrm{PDP}=$ perceived developmental purposes of teaching evaluation; $\mathrm{PCP}=$ Perceived control purposes of teaching evaluation; ST $=$ Recognition of the person conducting the follow-up session.

\section{Results}

Regarding the first hypothesis, the results indicate that teachers who perceive the purpose of the evaluation system as contributing to their professional development are more likely to perceive follow-up sessions with their nearest leader as useful for professional development $\left(\mathrm{b}_{(\mathrm{PDP} \rightarrow \mathrm{PUC})}=0.30\right)$. In contrast, whether teachers perceive the purpose of the evaluation system as controlling their work is not statistically related to whether they perceive the follow-up session as useful $\left(\mathrm{b}_{(\mathrm{PCP} \rightarrow \mathrm{PUC})}=0.04\right)$.

Turning to the second hypothesis, the findings indicate that perception of control purposes is the strongest indicator of reported levels of stress associated with the evaluation process $\left(b_{(\mathrm{PCP} \rightarrow \mathrm{STR})}=0.45\right)$. The path coefficient between teachers' reported level of recognition of the person who conducts the follow-up session and perceptions of the usefulness of the follow-up session is quite high $\left(\mathrm{b}_{(\mathrm{ST}-\mathrm{PUC})}=0.46\right)$. The path coefficient 
Lejonberg, E., Elstad, E. \& Christophersen, K.A. (2017). Teaching evaluation: antecedents of teachers' perceived usefulness of follow-up sessions and perceived stress related to the evaluation process. Teachers and Teaching: theory and practice.

http://www.tandfonline.com/doi/full/10.1080/13540602.2017.1399873

between recognition and stress is low $\left(\mathrm{b}_{(\mathrm{ST} \rightarrow \mathrm{STR})}=0.00\right)$, indicating that whether teachers have high or low recognition is not associated with whether they perceive the evaluation scheme as stressful. In addition, teachers who report that they perceive the communication from their leaders as clear are more likely to also report that they perceive the evaluation system as beneficial $\left(\mathrm{b}_{(\mathrm{CC} \rightarrow \mathrm{PUC})}=0.26\right)$. Whether leaders' communication is perceived as clear is unrelated to whether the evaluation scheme is perceived as stressful $\left(\mathrm{b}_{(\mathrm{CC} \rightarrow \mathrm{STR})}=0.05\right)$.

\section{Discussions and implications}

\subsection{Outcomes of the perceived purpose of teaching evaluations}

Among the most interesting findings of the perceived purpose of teaching evaluations, is that developmental purpose are positively related to perceived usefulness of follow-up sessions $\left(\mathrm{b}_{(\mathrm{PDP} \rightarrow \mathrm{PUC})}=0.30\right)$. Perceived control purpose are positively related to reported stress $\left(b_{(\mathrm{PCP} \rightarrow \mathrm{STR})}=0.45\right)$. These findings contrast with the conclusions of Delvaux et al. $(2013 \mathrm{~b})$, who finds beneficial outcomes from perceived summative purposes but not formative purposes. Our findings, however, are in line with Deneire et al. (2014), who notes beneficial outcomes from evaluation schemes with development purposes. Keeping and Levy (2000) highlight the importance of employees' reaction to appraisals, which they argue are likely to affect the outcomes.

The design of an evaluation scheme is likely to influence views of good teaching and teachers' practice and judgement of their success (Buchanan, 2015). Given that the declared purpose of the evaluation scheme is to contribute to teachers' continuing professional development, our results indicate the importance of communicating the developmental 
Lejonberg, E., Elstad, E. \& Christophersen, K.A. (2017). Teaching evaluation: antecedents of teachers' perceived usefulness of follow-up sessions and perceived stress related to the evaluation process. Teachers and Teaching: theory and practice.

http://www.tandfonline.com/doi/full/10.1080/13540602.2017.1399873

purpose to the actors involved. In Norway, education policymakers have recommended a development-oriented teaching-evaluation scheme (GNIST, 2014). However, our results show that a significant portion of teachers perceived the evaluation scheme as having a control purpose. Take, for instance, the mean score of 3.96 on a 7-point scale for the following statement: 'The purpose of teaching evaluation is to control teachers' classroom work'. The standard deviation is 1.9 , which reveals much variance and indicates that some teachers report perceiving quite high levels of control in teaching evaluation. The association found between perceived control purposes and teacher stress $\left(\mathrm{b}_{(\mathrm{PCP} \rightarrow \mathrm{STR})}=0.45\right)$ suggests that the lack of control purposes could be emphasised when informing teachers about teacher evaluation.

The finding that perceived control purposes are related to stress indicates that there is still a need for the communication of the purpose of teaching evaluation. As well, the use of such schemes is likely to influence perceptions of their purpose over time. Perceptions that evaluation and follow-up sessions have a control purpose is likely to decrease employees' eagerness to share their difficulties for the sake of the development (Hobson \& McIntyre, 2013; Kuvaas \& Dysvik, 2012). Uses of results from teaching evaluation contrary to the stated developmental purposes could undermine the potential beneficial effects. Abrahamsen and Aas (2014) reported that leaders conducting follow-up sessions found it challenging to convince teachers of their developmental intentions.

\subsection{Outcomes of recognition of the person responsible for the follow-up session}

There is a relatively high statistical association between recognition of the person who conducts follow-up sessions and perceived usefulness $\left(\mathrm{b}_{(\mathrm{ST}-\mathrm{PUC})}=0.46\right)$. This finding indicates that attention should be paid to matching teachers and the persons with whom they 
Lejonberg, E., Elstad, E. \& Christophersen, K.A. (2017). Teaching evaluation: antecedents of teachers' perceived usefulness of follow-up sessions and perceived stress related to the evaluation process. Teachers and Teaching: theory and practice.

http://www.tandfonline.com/doi/full/10.1080/13540602.2017.1399873

meet to discuss their professional development. This finding is not surprising as the literature highlights the challenges to matching in such potential developmental relationships (Clutterbuck, 2004; Hobson et al., 2009; Kram, 1988). It also underlines the importance of prioritising interpersonal skills when recruiting people for these tasks.

Based on the descriptive statistics presented in Table 1, we suggest that the overall perceived usefulness of follow-up sessions indicates unfulfilled potential which necessitates further training of appraisers. Levy and Williams (2004) point out several errors and biases to which appraisers are exposed. Such potential pitfalls illustrate why proper training is considered crucial to assist in teachers' professional development and provide high-quality feedback (Darling-Hammond, Amrein-Beardsley, Haertel, \& Rothstein, 2012; Duke \& Stiggins, 1986; Machell, 1995). Our results show that teachers have relatively high recognition of their leaders (the mean score for the relevant items is approximately 4.5 on the 7-point scale). However, the scores for the perceived usefulness of follow-up sessions are lower (approximately 3.5). This seeming discrepancy might be explained by the contested underlying assumption that students can provide useful feedback about teaching (Jambak, 2015). However, the mean scores for the perceived usefulness of evaluation are 4.1 (see appendix) but lower for the perceived usefulness of follow-up sessions (approximately 3.6). This gap supports the notion of untapped potential in follow-up sessions and indicates that there is room to improve the quality of the conversations to make them valuable in teachers' professional development.

As recognition of appraisers is crucial for the functioning of evaluation systems (Flores, 2010, 2012), this finding indicates that the investigated area has favourable growth conditions for implementation of an evaluation system. Assuming that 'feedback that will 
Lejonberg, E., Elstad, E. \& Christophersen, K.A. (2017). Teaching evaluation: antecedents of teachers' perceived usefulness of follow-up sessions and perceived stress related to the evaluation process. Teachers and Teaching: theory and practice.

http://www.tandfonline.com/doi/full/10.1080/13540602.2017.1399873

encourage growth comes from a credible source' (Duke \& Stiggins, 1986, p. 33) and that recognition of the appraiser is necessary but insufficient for follow-up sessions to contribute to professional development (Clutterbuck, 2004; Hobson et al., 2009; Kram, 1988), these results point to the need for further professionalisation of the mentoring skills of the midranking leaders. Wright (2004) finds beneficial outcomes from the training of appraisers and calls training a strategic issue 'for immediate remedial action for practice and policy' (p. 364). Other scholars also underline the importance of training evaluators (Darling-Hammond et al., 2012; Heneman \& Milanowski, 2003; Skrøwseth, 2008).

It is relevant to ask what kind of recognition we have measured. Abell, Dillon, Hopkins, McInerney, and O'Brien (1995) use the term 'professional respect' to distinguish between personal and professional recognition. This term emphasises that appreciation on a personal level does not necessarily translate to acknowledgement as a skilled professional. In our operationalisation, the term denotes respect and recognition in quite general terms. Further research on the recognition of mid-ranking leaders, specifically in their role as partners in teachers' work and professional development, would be of interest. Abrahamsen and Aas (2014) find that Norwegian heads of departments feel insecure when evaluating and guiding teachers. These findings underline the importance of training school leaders for this rather new role to exploit the potential of teaching evaluation schemes.

Another interesting finding is that recognition of the person responsible for the followup session is not statistically related to stress $\left(b_{(\mathrm{ST} \rightarrow \mathrm{STR})}=0.00\right)$. This result indicates that whether the teachers have a high or low recognition of the person who conducts the follow-up session is not relevant to whether they find participation in teaching evaluation stressful. 
Lejonberg, E., Elstad, E. \& Christophersen, K.A. (2017). Teaching evaluation: antecedents of teachers' perceived usefulness of follow-up sessions and perceived stress related to the evaluation process. Teachers and Teaching: theory and practice.

http://www.tandfonline.com/doi/full/10.1080/13540602.2017.1399873

\subsection{Outcomes of perceived clear communication from leadership}

Perceived clear communication from school leaders is related to perceived usefulness of follow-up sessions $\left(\mathrm{b}_{(\mathrm{CC} \rightarrow \mathrm{PUC})}=0.26\right)$. In addition, perception of communication as clear is not related to stress $\left(\mathrm{b}_{(\mathrm{CC} \rightarrow \mathrm{STR})}=0.05\right)$. These findings indicate that clear expectations for teachers from school leaders are beneficial in teaching evaluation. Perceived clear communication is also related to recognition of school leaders $\left(\mathrm{r}_{(\mathrm{ST} \leftrightarrow \mathrm{CC})}=.53\right)$, which suggests that participants who reported higher levels of perceived clear communication from leaders also reported higher levels of recognition of leaders. These findings are interesting as tradition in Norway emphasises a reticent approach, strives for symmetrical relationships (Abrahamsen \& Aas, 2014) and embraces reflection-based methods to contribute to others' professional development (Handal \& Lauvas, 1987). Our findings can be seen as an argument in favour of clear communication regarding professional development endeavours among teachers, which aligns with the findings of Lejonberg \& Tiplic (in progress) and Tuytens and Devos, 2013). Teachers should also receive training to upgrade their evaluation skills and ability to provide beneficial feedback (Duke \& Stiggins, 1986; Machell, 1995).

\subsection{Limitations}

This study has several limitations, particularly the parsimonious modelling and crosssectional nature of the design. Although employees' reactions to being evaluated are assumed to be important to benefit from performance appraisal (Levy \& Williams, 2004), the use of self-reported questionnaire data is a limitation. The subjective nature of such data is undeniable, and the heavy reliance on teachers' self-reports is questionable. In addition, only a small number of concepts were examined. The omitted variables might have influenced the 
Lejonberg, E., Elstad, E. \& Christophersen, K.A. (2017). Teaching evaluation: antecedents of teachers' perceived usefulness of follow-up sessions and perceived stress related to the evaluation process. Teachers and Teaching: theory and practice.

http://www.tandfonline.com/doi/full/10.1080/13540602.2017.1399873

overall model, and reverse causation may play a role. Longitudinal research is needed to address the complexity of the phenomenon. Another limitation is the small sample of teachers. These shortcomings suggest directions for future research.

\section{Concluding Remarks}

A link between continued follow-up and support and teachers' professional development has been acknowledged (Guskey, 2002). Given the importance of feedback in follow-up sessions for teaching evaluation (Delvaux et al., 2013b), this article provides additional insight, highlighting potential drivers of the perceived usefulness of follow-up sessions. This finding indicates the importance of using evaluation for development-oriented purposes and of clearly communicating such intentions to all involved participants.

Further, we highlight that recognition of the person responsible for the follow-up session is related to perceived usefulness. Therefore, the training and recruitment of leaders and the matching of teachers and leaders are likely to be important. Clear communication is identified as a variable associated with teachers' perceptions of the usefulness of teaching evaluation and is related to recognition of the person who conducts the follow-up session. We also argue that proper preparation is crucial for school leaders to help teachers in their professional development. 
Lejonberg, E., Elstad, E. \& Christophersen, K.A. (2017). Teaching evaluation: antecedents of teachers' perceived usefulness of follow-up sessions and perceived stress related to the evaluation process. Teachers and Teaching: theory and practice.

http://www.tandfonline.com/doi/full/10.1080/13540602.2017.1399873

\section{References}

Abell, S. K., Dillon, D. R., Hopkins, C. J., McInerney, W. D., \& O’Brien, D. G. (1995).

"Somebody to count on": Mentor/intern relationships in a beginning teacher internship program. Teaching and Teacher Education, 11(2), 173-188.

Abrahamsen, H., \& Aas, M. (2014). Avdelingsledere-en ny profesjon innenfor skoleledelse [Midle leaders - a new profession within school leadership]. In E. Elstad \& K. Helstad (Eds.), Profesjonsutvikling i skolen [Professional development in school] (pp. 300311). Oslo, Norway: Universitesforlaget.

Akershus County (2013). Mal for oppfølgingssamtale [Guide for follow-up session]. Unpublished guide.

Akershus County (2014). Protokoll fra møte i Hovedutvalg for utdanning og kompetanse 01.12.2014 [Protocol from meeting in the Council of Education and Skills]. In H. F. U. O. Kompetanse.

Austin, V., Shah, S., \& Muncer, S. (2005). Teacher stress and coping strategies used to reduce stress. Occupational Therapy International, 12(2), 63-80.

Author (2014)

Author (2014)

Author \& College (in press)

Authors (2015)

Bakx, A., Koopman, M., de Kruijf, J., \& den Brok, P. (2015). Primary school pupils' views of characteristics of good primary school teachers: An exploratory, open approach for investigating pupils' perceptions. Teachers and Teaching, 21(5), 543-564. 
Lejonberg, E., Elstad, E. \& Christophersen, K.A. (2017). Teaching evaluation: antecedents of teachers' perceived usefulness of follow-up sessions and perceived stress related to the evaluation process. Teachers and Teaching: theory and practice.

http://www.tandfonline.com/doi/full/10.1080/13540602.2017.1399873

Bartlett, S. (1998). The development of effective appraisal by teachers. Journal of In-Service Education, 24(2), 227-238.

Blau, G. (1999). Testing the longitudinal impact of work variables and performance appraisal satisfaction on subsequent overall job satisfaction. Human Relations, 52(8), 10991113.

Blossing, U., Imsen, G., \& Moos, L. (2013). The Nordic Education Model. New York: Springer.

Brunvoll, P.-A. (2014). Statusrapport for Undervisningsvurderingen 2013-2014 [report from teaching evaluation 2013-2014], Akershus Fylkeskommune.

Buchanan, R. (2015). Teacher identity and agency in an era of accountability. Teachers and Teaching, 21(6), 700-719.

Clutterbuck, D. (2004). Everyone needs a mentor: Fostering talent in your organisation. London: CIPD Publishing.

Colbjørnsen, T. (2014). Profesjonalisering og profesjonsutvikling av skoleledelse i Norge [Professionalizing and professional development of school leadership in Norway]. In E. Elstad \& K. Helstad (Eds.), Profesjonsutvikling i skolen [Professional development in school] (pp. 244-258). Oslo, Norway: Universitetsforlaget.

Conley, S., Smith, J. L., Collinson, V., \& Palazuelos, A. (2016). A small step into the complexity of teacher evaluation as professional development. Professional Development in Education, 1-3.

Darling-Hammond, L., Amrein-Beardsley, A., Haertel, E., \& Rothstein, J. (2012). Evaluating teacher evaluation. Phi Delta Kappan, 8-15. 
Lejonberg, E., Elstad, E. \& Christophersen, K.A. (2017). Teaching evaluation: antecedents of teachers' perceived usefulness of follow-up sessions and perceived stress related to the evaluation process. Teachers and Teaching: theory and practice.

http://www.tandfonline.com/doi/full/10.1080/13540602.2017.1399873

Darling-Hammond, L., Amrein-Beardsley, A., Haertel, E. H., \& Rothstein, J. (2011). Getting teacher evaluation right: A background paper for policy makers. National Academy of Education (NJ1).

Darling-Hammond, L., Wise, A. E., \& Pease, S. R. (1983). Teacher evaluation in the organizational context: A review of the literature. Review of Educational Research, $53(3), 285-328$.

Day, C., \& Gu, Q. (2007). Variations in the conditions for teachers' professional learning and development: Sustaining commitment and effectiveness over a career. Oxford Review of Education, 33(4), 423-443.

Day, C., Stobart, G., Sammons, P., Kington, A., Gu, Q., Smees, R., \& Mujtaba, T. (2006). Variations in teachers' work, lives and effectiveness. Final report for the VITAE Project, DfES.

Delvaux, E., Vanhoof, J., Tuytens, M., Vekeman, E., Devos, G., \& Van Petegem, P. (2013a). How may teacher evaluation have an impact on professional development? A multilevel analysis. Teaching and Teacher Education, 36, 1-11.

Delvaux, E., Vanhoof, J., Tuytens, M., Vekeman, E., Devos, G., \& Van Petegem, P. (2013b). How may teacher evaluation have an impact on professional development? A multilevel analysis. Teaching and Teacher Education, 36(0), 1-11. doi:http://dx.doi.org/10.1016/j.tate.2013.06.011

Deneire, A., Vanhoof, J., Faddar, J., Gijbels, D., \& Van Petegem, P. (2014). Characteristics of appraisal systems that promote job satisfaction of teachers. Education Research and Perspectives, 41, 94-114.

Duke, D. L., \& Stiggins, R. J. (1986). Teacher evaluation: Five keys to growth. West Haven: NEA Publications. 
Lejonberg, E., Elstad, E. \& Christophersen, K.A. (2017). Teaching evaluation: antecedents of teachers' perceived usefulness of follow-up sessions and perceived stress related to the evaluation process. Teachers and Teaching: theory and practice.

http://www.tandfonline.com/doi/full/10.1080/13540602.2017.1399873

Firestone, W. A. (2014). Teacher evaluation policy and conflicting theories of motivation. Educational Researcher, 0013189X14521864.

Flores, M. A. (2010). Teacher performance appraisal in Portugal: The (im)possibilities of a contested model. Mediterranean Journal of Educational Studies, 15(1), 41-60.

Flores, M. A. (2012). The implementation of a new policy on teacher appraisal in Portugal: How do teachers experience it at school? Educational Assessment, Evaluation and Accountability, 24(4), 351-368.

Garet, M. S., Porter, A. C., Desimone, L., Birman, B. F., \& Yoon, K. S. (2001). What makes professional development effective? Results from a national sample of teachers. American educational research journal, 38(4), 915-945.

Goe, L., Holdheide, L., \& Miller, T. (2013). A practical guide to designing comprehensive teacher evaluation systems. A tool to assist in the development of teacher evaluation systems. Retrieved from http://www.lauragoe.com/LauraGoe/practicalGuideEvalSystems.pdf

Guskey, T. R. (2002). Professional development and teacher change. Teachers and Teaching: Theory and Practice, 8(3), 381-391.

Haladyna, T. M., \& Rodriguez, M. C. (2013). Developing and validating test items. Routledge.

Handal, G., \& Lauvas, P. (1987). Promoting reflective teaching: Supervision in practice: Philadelphia, PA: Society for Research into Higher Education.

Heck, R. H. (1992). Principals' instructional leadership and school performance: Implications for policy development. Educational Evaluation and Policy Analysis, 14(1), 21-34. doi:10.2307/1164525 
Lejonberg, E., Elstad, E. \& Christophersen, K.A. (2017). Teaching evaluation: antecedents of teachers' perceived usefulness of follow-up sessions and perceived stress related to the evaluation process. Teachers and Teaching: theory and practice.

http://www.tandfonline.com/doi/full/10.1080/13540602.2017.1399873

Helgøy, I., \& Homme, A. (2006). Policy tools and institutional change: Comparing education policies in Norway, Sweden and England. Journal of Public Policy, 26(02), 141-165.

Heneman, H. G., \& Milanowski, A. T. (2003). Continuing assessment of teacher reactions to a standards-based teacher evaluation system. Journal of Personnel Evaluation in Education, 17(2), 173-195.

Hill, H. C., \& Grossman, P. (2013). Learning from teacher observations: Challenges and opportunities posed by new teacher evaluation systems. Harvard Educational Review, 83(2), 371-384.

Hobson, A. J., Ashby, P., Malderez, A., \& Tomlinson, P. D. (2009). Mentoring beginning teachers: What we know and what we don't. Teaching and Teacher Education, 25(1), 207-216.

Hobson, A. J., \& Malderez, A. (2013). Judgementoring and other threats to realizing the potential of school-based mentoring in teacher education. International Journal of Mentoring and Coaching in Education, 2(2), 89-108.

Hobson, A. J., \& McIntyre, J. (2013). Teacher fabrication as an impediment to professional learning and development: The external mentor antidote. Oxford Review of Education, $39(3), 345-365$.

Isoré, M. (2009). Teacher evaluation: Current practices in OECD countries and a literature review (Vol. 23). Paris, France: Organisation for Economic Cooperation and Development Publishing.

Jambak, T. (2015). En dårlig lærers bekjennelser [confessions from a poor teacher]. Aftenposten. Retrieved from http://www.aftenposten.no/meninger/kronikker/Endarlig-larers-bekjennelser-7516999.html 
Lejonberg, E., Elstad, E. \& Christophersen, K.A. (2017). Teaching evaluation: antecedents of teachers' perceived usefulness of follow-up sessions and perceived stress related to the evaluation process. Teachers and Teaching: theory and practice.

http://www.tandfonline.com/doi/full/10.1080/13540602.2017.1399873

Keeping, L. M., \& Levy, P. E. (2000). Performance appraisal reactions: Measurement, modeling, and method bias. Journal of applied psychology, 85(5), 708-723.

Kelly, K. O., Ang, S. Y. A., Chong, W. L., \& Hu, W. S. (2008). Teacher appraisal and its outcomes in Singapore primary schools. Journal of Educational Administration, 46(1), $39-54$.

Kluger, A. N., \& DeNisi, A. (1996). The effects of feedback interventions on performance: A historical review, a meta-analysis, and a preliminary feedback intervention theory. Psychological Bulletin, 119(2), 254-284. doi:10.1037/0033-2909.119.2.254

Kram, K. E. (1988). Mentoring at work: Developmental relationships in organizational life. Maryland: University Press of America.

Kuvaas, B. (2011). The interactive role of performance appraisal reactions and regular feedback. Journal of Managerial Psychology, 26(2), 123-137.

Kuvaas, B., \& Dysvik, A. (2012). Kapittel 9. Administrative og utviklende medarbeidersamtaler. In B. Kuvaas \& A. Dysvik (Eds.), Lønnsomhet gjennom menneskelige ressurser. Evidensbasert HRM (Vol. 2). Bergen, Norway: Fagbokforlaget.

Kyriacou, C., \& Sutcliffe, J. (1978). Teacher stress: Prevalence, sources, and symptoms. British Journal of Educational Psychology, 48(2), 159-167.

Leithwood, K. (1994). Leadership for school restructuring. Educational Administration Quarterly, 30(4), 498-518.

Levy, P. E., \& Williams, J. R. (2004). The social context of performance appraisal: A review and framework for the future. Journal of Management, 30(6), 881-905. 
Lejonberg, E., Elstad, E. \& Christophersen, K.A. (2017). Teaching evaluation: antecedents of teachers' perceived usefulness of follow-up sessions and perceived stress related to the evaluation process. Teachers and Teaching: theory and practice.

http://www.tandfonline.com/doi/full/10.1080/13540602.2017.1399873

Litt, M. D., \& Turk, D. C. (1985). Sources of stress and dissatisfaction in experienced high school teachers. The Journal of Educational Research, 78(3), 178-185.

Machell, J. (1995). The teacher evaluation environment: An examination of attributes related to teacher growth. Journal of Personnel Evaluation in Education, 9(3), 259-273. doi:10.1007/BF00972641

Mo, K. W., Conners, R., \& McCormick, J. (1998). Teacher appraisal in Hong Kong selfmanaging secondary schools: Factors for effective practices. Journal of Personnel Evaluation in Education, 12(1), 19-42.

Nishii, L. H., Lepak, D. P., \& Schneider, B. (2008). Employee attributions of the 'why' of HR practices: Their effects on employee attitudes and behaviors, and customer satisfaction. Personnel Psychology, 61(3), 503-545.

Organisation for Economic Cooperation and Development (2009). Teacher evaluation. A conceptual framework and examples of country practices. Retrieved from www.oecd.org/edu/school/44568106.pdf

Organisation for Economic Cooperation and Development (2011). OECD reviews of evaluation and assessment in education Norway 2011. Retrieved from www.oecd.org/norway/48632032.pdf

Ovando, M. N., \& Ramirez Jr, A. (2007). Principals' instructional leadership within a teacher performance appraisal system: Enhancing students' academic success. Journal of Personnel Evaluation in Education, 20(1-2), 85-110. 
Lejonberg, E., Elstad, E. \& Christophersen, K.A. (2017). Teaching evaluation: antecedents of teachers' perceived usefulness of follow-up sessions and perceived stress related to the evaluation process. Teachers and Teaching: theory and practice.

http://www.tandfonline.com/doi/full/10.1080/13540602.2017.1399873

Richter, D., Kunter, M., Klusmann, U., Lüdtke, O., \& Baumert, J. (2011). Professional development across the teaching career: Teachers' uptake of formal and informal learning opportunities. Teaching and Teacher Education, 27(1), 116-126.

Skrøwseth, S. (2008). Skolevandring. Et nytt verktøy for ledelse og laering. Troms $\emptyset$, Norway: Eureka Forlag.

Smylie, M. A. (2014). Teacher evaluation and the problem of professional development. MidWestern Educational Researcher, 26(2), 97-111.

Tuytens, M., \& Devos, G. (2010). The influence of school leadership on teachers' perception of teacher evaluation policy. Educational Studies, 36(5), 521-536.

Tuytens, M., \& Devos, G. (2012). Importance of system and leadership in performance appraisal. Personnel Review, 41(6), 756-776.

Tuytens, M., \& Devos, G. (2013). The problematic implementation of teacher evaluation policy School failure or governmental pitfall? Educational Management Administration \& Leadership, doi:1741143213502188.

Wright, R. P. (2004). Mapping cognitions to better understand attitudinal and behavioral responses in appraisal research. Journal of Organizational Behavior, 25(3), 339-374. Day, C., \& Gu, Q. (2007). Variations in the conditions for teachers' professional learning and development: Sustaining commitment and effectiveness over a career. Oxford Review of Education, 33(4), 423-443. 
Lejonberg, E., Elstad, E. \& Christophersen, K.A. (2017). Teaching evaluation: antecedents of teachers' perceived usefulness of follow-up sessions and perceived stress related to the evaluation process.

Teachers and Teaching: theory and practice.

http://www.tandfonline.com/doi/full/10.1080/13540602.2017.1399873 